\title{
Effect of amifostine on sperm DNA fragmentation and testes after radioiodine treatment
}

\author{
Cigdem Cebi Sen ${ }^{1}$, Nihat Yumusak ${ }^{2}$, Hasan Ikbal Atilgan ${ }^{3}$, \\ Murat Sadic ${ }^{4}$, Gokhan Koca ${ }^{4}$, Meliha Korkmaz ${ }^{4}$ \\ ${ }^{1}$ Department of Reproduction and Artificial Insemination, ${ }^{2}$ Department of Pathology, \\ Faculty of Veterinary Medicine, Harran University, 63200 Sanliurfa, Turkey, \\ ${ }^{3}$ Department of Nuclear Medicine, Kahramanmaras Necip Fazil City Hospital, 46000 Kahramanmaras, Turkey \\ ${ }^{4}$ Department of Nuclear Medicine, Ankara Training and Research Hospital, \\ University of Health Sciences, 06100 Ankara, Turkey \\ cigdemcebi@hotmail.com
}

\begin{abstract}
Introduction: Radioactive iodine (RAI) is commonly used for the treatment of hyperthyroidism caused by Graves' disease or thyroid nodules. However, information available on the impact of RAI therapy on male gonadal function is scarce. This study aimed to determine any possible damage to testicular tissue and sperm quality caused by RAI therapy, and the radioprotective effect of amifostine against such damage. Material and Methods: In total, 36 rats were randomly allocated to three groups, including a control group, RAI group (111 MBq Iodine-131), and RAI + amifostine group (111 MBq Iodine-131 and a single dose of $200 \mathrm{mg} / \mathrm{kg}$ amifostine). Blood and epididymal sperm samples were taken for hormone analyses and the evaluation of spermatological parameters. The TUNEL assay and haematoxylin-eosin were used to stain testicular tissue samples to detect histological changes and apoptosis. Results: The groups differed insignificantly for the testicular mass index and spermatozoa concentration. However, spermatozoa motility and percentage of viable spermatozoa were higher in the RAI + amifostine group, compared to the RAI group. Sperm DNA fragmentation and the index of apoptotic germ cells significantly decreased in the amifostine group, in comparison to the radioiodine group. While the testosterone levels showed no significant change, the follicle stimulating hormone (FSH) levels significantly decreased in the RAI + amifostine group. Conclusion: All histopathological parameters and some spermatological parameters showed that RAI therapy caused statistically significant damage of testicular tissue and this damage was reduced by amifostine.
\end{abstract}

Keywords: testes, radioiodine, apoptosis, amifostine, sperm DNA.

\section{Introduction}

Radioactive iodine, colloquially known as "atom", is the radioactive form of iodine which emits radiation. Radioiodine (RAI) therapy aims to obtain maximum tumour control with minimum normal tissue toxicity. After being administered in capsule or liquid form by oral route, radioactive iodine-131 (I-131) is absorbed from the intestines and passes into the blood circulation, finally accumulating in cancer cells. The radiation it emits ceases the growth and activity of cancer cells. As its half-life is eight days, I-131 remains and shows activity in cancer tissue for a relatively long time (16). Depending on the interaction of radiation with normal tissue, side effects may develop in the early or late period. The most common side effects observed after therapy include salivary gland damage and may be also observed in the bone marrow, lungs, ovaries, and testes (12). Iodoproteins in the blood circulation and I-131 in the bladder and gut are the primary sources of radiation to the gonads resulting from I-131 therapy (21). Despite technological developments, it is still not possible to fully eliminate the early and late complications of RAI therapy. For this reason, various radioprotective agents are used to prevent radiation-induced tissue damage following RAI therapy. Currently, several radioprotective substances, belonging to various chemical groups, are available and extensive research is ongoing. The most commonly used radioprotective agent is amifostine, which is a cysteamine analogue and an inactive pro- 
drug, also known as WR-2721. The phosphorus in the structure of amifostine maintains this compound in the inactive form, whilst sulphur earns it a radical scavenging activity (7). Available data on the effects of I-131 treatment on male gonadal functions are very scarce. In view of this scarcity, the present study aimed to determine the impact of RAI therapy on sperm quality and histopathological changes it causes in the testicular tissue, and to investigate the radioprotective effect of amifostine against RAI therapy-induced damage.

\section{Material and Methods}

Animals. In total, 36 male Wistar albino rats, aged 3-5 months and weighing 200-250 g, were used. The rats were free from diseases and deformities. The animals were acclimated to the laboratory conditions for a minimum of one week before the study began. All rats were housed under controlled humidity $(55 \% \pm 10 \%)$, temperature $\left(21^{\circ} \mathrm{C} \pm 2\right)$, and lighting $(12 \mathrm{~h}$ dark: $12 \mathrm{~h}$ light) with free access to standard feed and water. The rats were kept in poly-propylene cages with disposable absorbent cloths under sterile paddy husks to avoid their contamination with radioactive urine.

Study design. Rats were randomly assigned to three equal groups: control group (group 1), group which received RAI alone (group 2), and group treated with a combination of RAI + amifostine (group 3). The animals of control group were maintained for control purposes and accordingly were administered $1 \mathrm{~mL}$ of $\mathrm{NaCl}$ solution by intraperitoneal route. The rats of group 2 (group RAI) were orally administered $111 \mathrm{MBq}$ (3 mCi) of RAI (Mon-Iyot-131 Eczacıbaş1/Monrol Nukleer Urunler Sanayi ve Ticaret AS, Gebze, Kocaeli, Turkey) alone, and rats of group 3 (group RAI + amifostine) were given a single dose of amifostine (200 mg/kg b.w.) by intraperitoneal route $1 \mathrm{~h}$ prior to the oral administration of RAI.

Hormone analyses. On the $8^{\text {th }}$ day of the trial, blood samples were taken from all rats by cardiac puncture into no-additive tubes. Serum was extracted from the blood samples by centrifugation at 2,200 $\mathrm{g}$ and at $4^{\circ} \mathrm{C}$ for $15 \mathrm{~min}$ and the serum samples were stored at $-20^{\circ} \mathrm{C}$ until hormone analyses. The serum testosterone and FSH levels were measured by ELISA according to the manufacturer's instructions (Cusabio, China).

Calculation of the testicular mass index (TMI). On the $8^{\text {th }}$ day of the trial, the rats were decapitated after being anaesthetised with propofol (Abbott Laboratuvarları, Turkey) administered at a dose of $50 \mathrm{mg} / \mathrm{kg}$ by intraperitoneal route. The testicular tissue was extracted immediately after decapitation. The sum of the weights of the right and left testes of the same animal was divided by the body weight measured on the last day of the trial, and the result was multiplied by 100 to calculate the TMI for each animal (22).

Epididymal sperm evaluation. In order to flush out the blood, the testes of each animal were placed in a hollow plate containing isotonic saline solution. By using a pair of fine-pointed scissors and applying compression with forceps, the left caudal epididymidis was cut longitudinally. By cutting the caudal epididymidis into small pieces, the sperm cells were released in Petri dishes containing phosphate-buffered saline (PBS), and were analysed for sperm characteristics. Sperm quality was determined on the basis of five parameters: sperm count, viability, motility, and sperm DNA fragmentation. A haemocytometer was used to measure sperm concentration (23). Following 1:200 dilution with PBS, suspensions of sperm from the caudal epididymis were transferred into microcentrifuge tubes. After the diluted samples were loaded into the counting chamber, spermatozoon counts were performed under a light microscope, using a haemocytometer with Neubauer ruling. Average sperm motility, determined on the basis of motile and non-motile spermatozoa counts, was expressed as percentage motility (23).

Assessment of sperm plasma membrane. A fluorescent 'live/dead kit' (Molecular Probes, USA) containing propidium iodide (PI) and SYBR-14 was used to determine sperm membrane integrity. Firstly, $5 \mu \mathrm{L}$ of SYBR-14 was added to diluted sperm, after maintaining at $38.5^{\circ} \mathrm{C}$ for $5 \mathrm{~min}, 5 \mu \mathrm{L}$ of PI was added to the sperm. After $5 \mathrm{~min}, 3 \mu \mathrm{L}$ of each sample was placed on a glass slide, covered with a coverslip, and 100 spermatozoa were counted with an OLYMPUS BX51 fluorescent microscope. Samples displaying red fluorescence after being stained with PI were classified as non-viable, while those displaying green fluorescence after being stained with SYBR-14 were classified as viable (24) (Fig. 1b).

Assessment of sperm DNA fragmentation. The samples were processed in line with the protocol of the Sperm-Halomax-Mus kit (Halotech DNA, Spain) for the assessment of sperm DNA fragmentation. Sperm with large, spotty halos of chromatin dispersion were classified as having DNA fragmentation, whilst those showing small, compact halos of chromatin dispersion were classified as having no fragmentation (Fig. 1a). The groups were compared according to the DNA fragmentation index (DFI) calculated (19).

Histopathological analysis. On the $8^{\text {th }}$ day of the trial, testicular tissue was extracted from each decapitated rat and fixed in $10 \%$ neutral buffered formalin solution ( $\mathrm{pH} 7.2-7.4$ ). Following routine tissue processing and paraffin embedding performed overnight, standard $4-\mu \mathrm{m}$-thick sections were cut and the first three sections as well as the $10^{\text {th }}$ section from each testis were stained with haematoxylin-eosin. After being cover-slipped, all of the samples were thoroughly examined using a high-resolution light microscope (Olympus BX-53; Japan). All changes observed in the sections were noted and graded on the basis of the presence and severity of any particular finding and classified as follows: negative $(-)$, mild $(+)$, moderate $(++)$, or severe $(+++)(11)$. 
In-situ detection of apoptotic cells by the TUNEL assay. To determine apoptosis-related DNA breaks in the germ cells, the deoxynucleotidyl transferase (TdT)-mediated dUTP-digoxigenin nick end-labelling (TUNEL) assay was performed according to the manufacturer's instructions (In Situ Cell Death Detection Kit, POD, Roche, Germany). Standard five micrometre-thick tissue sections mounted on poly-Llysine-coated glass slides were deparaffinised and rehydrated. The tissues were first washed in distilled water and then immersed in a $3 \% \mathrm{H}_{2} \mathrm{O}_{2}$ solution, and treated with methanol for $20 \mathrm{~min}$. After being washed three times in PBS, the sections were incubated at room temperature for $15 \mathrm{~min}$ with freshly prepared proteinase $\mathrm{K}(20 \mu \mathrm{L} / \mathrm{mL}$; Roche, Germany). Then after washing the tissues three times in PBS, $50 \mu \mathrm{L}$ of the TUNEL reaction mixture (containing TdT and dUTP) was added and gently mixed to ensure homogeneity. Drops of this mixture were added to the preparations. The preparations were incubated at $37^{\circ} \mathrm{C}$ in the dark in a humid chamber for $1 \mathrm{~h}$. After being washed in PBS 3 times, each time for $5 \mathrm{~min}$, all preparations were instilled with $50 \mu \mathrm{L}$ of anti-fluorescein antibody conjugated POD (peroxidase), and subsequently incubated at $37^{\circ} \mathrm{C}$ in a humidity chamber for $30 \mathrm{~min}$. Next, the sections were treated with AEC (3-amino-9-ethyl carbazole, Dako, Denmark) for $10 \mathrm{~min}$. Finally, the sections were stained with Mayer's haematoxylin for background contrast and examined under a light microscope (30). For the calculation of the apoptotic index, the number of apoptotic germ cells per tubule was calculated for each testis, based on the percentages of the stained nuclei for these three markers, the following criteria were used: negative $-0(<1 \%$ positive); weak $-1(1 \%$ to $25 \%$ positive); intermediate -2 ( $>25 \%$ to $75 \%$ positive); strong -3 ( $>75 \%$ positive).

Statistical analysis. Statistical analysis of the results was performed using the SPSS ${ }^{\circledR}$ (SPSS 14.0, USA) software package. The distribution of the data was assessed with the Shapiro-Wilk test. The groups were compared with nonparametric tests, as the data did not show a normal distribution. Statistical differences between the groups were assessed with the KruskalWallis H-test and the Bonferroni corrected MannWhitney U-test. The chi-square test was used to determine statistically significant differences between the pathological variables. Results were given as mean \pm standard deviation $(\mathrm{X} \pm \mathrm{SD})$. The level of statistical significance was set at $\mathrm{P}<0.05$.

\section{Results}

Results of the TMI for different groups are presented in Table 1. The comparison of the groups (control group, group RAI, and group RAI + amifostine) showed that no statistically significant difference existed (P $>0.05$; Table 1). While sperm motility was decreased in the group that received RAI alone, in comparison to the other groups, in the case of the group which received RAI + amifostine sperm motility was higher in comparison to the group that received RAI alone. The results of the sperm analyses are presented in Table 1. Compared to the control group, sperm viability significantly declined in the treatment groups $(\mathrm{P}<$ $0.001)$. While sperm viability was higher in group RAI + amifostine compared to group RAI, the same parameter was lower in group RAI, when compared to the control group. The three groups significantly differed from each other in terms of sperm motility and viability, and the differences observed between the groups for sperm concentration were found to be statistically insignificant $(\mathrm{P}>0.05)$ (Table 1). Sperm DNA fragmentation index was $3.08 \% \pm 0.25$ in the control group, $14.91 \% \pm 0.43$ in group RAI, and $9.08 \% \pm 0.35$ in group RAI + amifostine, and the differences between the groups were statistically significant $(\mathrm{P}<0.001)$. The comparison of group RAI with group RAI + amifostine for the sperm DNA fragmentation index revealed that an increase in the index was statistically significant $(\mathrm{P}<0.001)$ in group RAI.

Table 1. Investigated parameters in the different studied groups $\quad \pm$

\begin{tabular}{|c|c|c|c|c|c|}
\hline Variables & Descriptives & $\begin{array}{l}\text { Control } \\
(\mathrm{n}=12)\end{array}$ & $\begin{array}{c}\text { RAI } \\
(\mathrm{n}=12)\end{array}$ & $\begin{array}{c}\text { RAI+amifostine } \\
(\mathrm{n}=12)\end{array}$ & $\mathrm{P}$ \\
\hline TMI (g) & $\begin{array}{l}\text { Mean } \pm \text { SD } \\
\text { Median }\end{array}$ & $\begin{array}{c}1.34 \pm 0.16^{\mathrm{a}} \\
1.31\end{array}$ & $\begin{array}{c}1.35 \pm 0.14^{\mathrm{a}} \\
1.33\end{array}$ & $\begin{array}{c}1.40 \pm 0.18^{\mathrm{a}} \\
1.38\end{array}$ & $\mathrm{P}>0.05$ \\
\hline Sperm motility (\%) & $\begin{array}{l}\text { Mean } \pm \text { SD } \\
\text { Median }\end{array}$ & $\begin{array}{c}74.58 \pm 3.34^{\mathrm{c}} \\
75.0\end{array}$ & $\begin{array}{c}18.75 \pm 3.76^{\mathrm{a}} \\
20.0\end{array}$ & $\begin{array}{c}39.58 \pm 3.34^{\mathrm{b}} \\
40.0\end{array}$ & $\mathrm{P}<0.001$ \\
\hline $\begin{array}{l}\text { Sperm concentration } \\
\text { (millons } / \mathrm{mL} \text { ) }\end{array}$ & $\begin{array}{l}\text { Mean } \pm \text { SD } \\
\text { Median }\end{array}$ & $\begin{array}{c}75.31 \pm 5.5^{\mathrm{a}} \\
75.75\end{array}$ & $\begin{array}{c}74.57 \pm 3.55^{\mathrm{a}} \\
73.75\end{array}$ & $\begin{array}{c}76.81 \pm 5.67^{\mathrm{a}} \\
75.0\end{array}$ & $\mathrm{P}>0.05$ \\
\hline $\begin{array}{l}\text { Viable spermatozoa } \\
\text { rate }(\%)\end{array}$ & $\begin{array}{l}\text { Mean } \pm \mathrm{SD} \\
\text { Median }\end{array}$ & $\begin{array}{c}81.91 \pm 2.77^{\mathrm{c}} \\
80.0\end{array}$ & $\begin{array}{c}18.41 \pm 2.81^{\mathrm{a}} \\
19.0\end{array}$ & $\begin{array}{c}41.83 \pm 4.66^{\mathrm{b}} \\
42.5\end{array}$ & $\mathrm{P}<0.001$ \\
\hline $\begin{array}{l}\text { Sperm DNA } \\
\text { fragmentation rate } \\
(\%)\end{array}$ & $\begin{array}{l}\text { Mean } \pm \text { SD } \\
\text { Median }\end{array}$ & $\begin{array}{c}3.08 \pm 0.9^{\mathrm{a}} \\
\quad 3.0\end{array}$ & $\begin{array}{c}14.91 \pm 1.5^{\mathrm{c}} \\
15.0\end{array}$ & $\begin{array}{c}9.08 \pm 1.24^{\mathrm{b}} \\
9.0\end{array}$ & $\mathrm{P}<0.001$ \\
\hline $\begin{array}{l}\text { Serum testosterone } \\
\text { concentration }(\mathrm{ng} / \mathrm{mL})\end{array}$ & $\begin{array}{l}\text { Mean } \pm \mathrm{SD} \\
\text { Median }\end{array}$ & $\begin{array}{c}3.19 \pm 1.21^{\mathrm{a}} \\
3.49\end{array}$ & $\begin{array}{c}3.78 \pm 1.69^{\mathrm{a}} \\
3.71\end{array}$ & $\begin{array}{c}3.68 \pm 1.66^{\mathrm{a}} \\
3.29\end{array}$ & $\mathrm{P}>0.05$ \\
\hline $\begin{array}{l}\text { Serum FSH } \\
\text { concentration } \\
(\mathrm{mIU} / \mathrm{mL})\end{array}$ & $\begin{array}{l}\text { Mean } \pm \text { SD } \\
\text { Median }\end{array}$ & $\begin{array}{c}22.34 \pm 4.72^{\mathrm{a}} \\
21.48\end{array}$ & $\begin{array}{c}80.04 \pm 5.71^{\mathrm{c}} \\
80.62\end{array}$ & $\begin{array}{c}51.63 \pm \\
7.28^{\mathrm{b}} \\
50.89\end{array}$ & $\mathrm{P}<0.001$ \\
\hline
\end{tabular}

Data are mean \pm standard deviation $(\mathrm{SD})$ of the mean, groups with different superscripts $(\mathrm{a}, \mathrm{b}, \mathrm{c})$ in the same row are significantly different, TMI - testicular mass index 
Table 2. TUNEL results and testis histological damage scoring in all experimental groups

\begin{tabular}{lccc}
\hline Variables & $\begin{array}{c}\text { Control } \\
(\mathrm{n}=12)\end{array}$ & $\begin{array}{c}\text { RAI } \\
(\mathrm{n}=12)\end{array}$ & $\begin{array}{c}\text { RAI + amifostine } \\
(\mathrm{n}=12)\end{array}$ \\
\hline Germ cell loss & - & ++ & + \\
$\begin{array}{l}\text { Degenerative changes in } \\
\text { seminiferous epithelium }\end{array}$ & - & ++ & + \\
$\begin{array}{l}\text { Germinal cell detachment } \\
\text { Vacuolation in the germinal cells }\end{array}$ & - & ++ & + \\
$\begin{array}{l}\text { Disorganisation of seminiferous } \\
\text { epithelium }\end{array}$ & - & ++ & + \\
*Apoptotic index in germ cells & - & +++ & + \\
\hline
\end{tabular}

$(-)$ - no lesions, $(+)-$ mild lesions, $(++)-$ moderate lesions, $(+++)-$ severe lesions. *The intensity of staining was scored as $-(<1 \%$ positive $),+(1$ to $25 \%$ positive $),++(>25 \%$ to $75 \%$ positive $),+++(>75 \%$ positive $)$ according to the percentage of positive staining cells
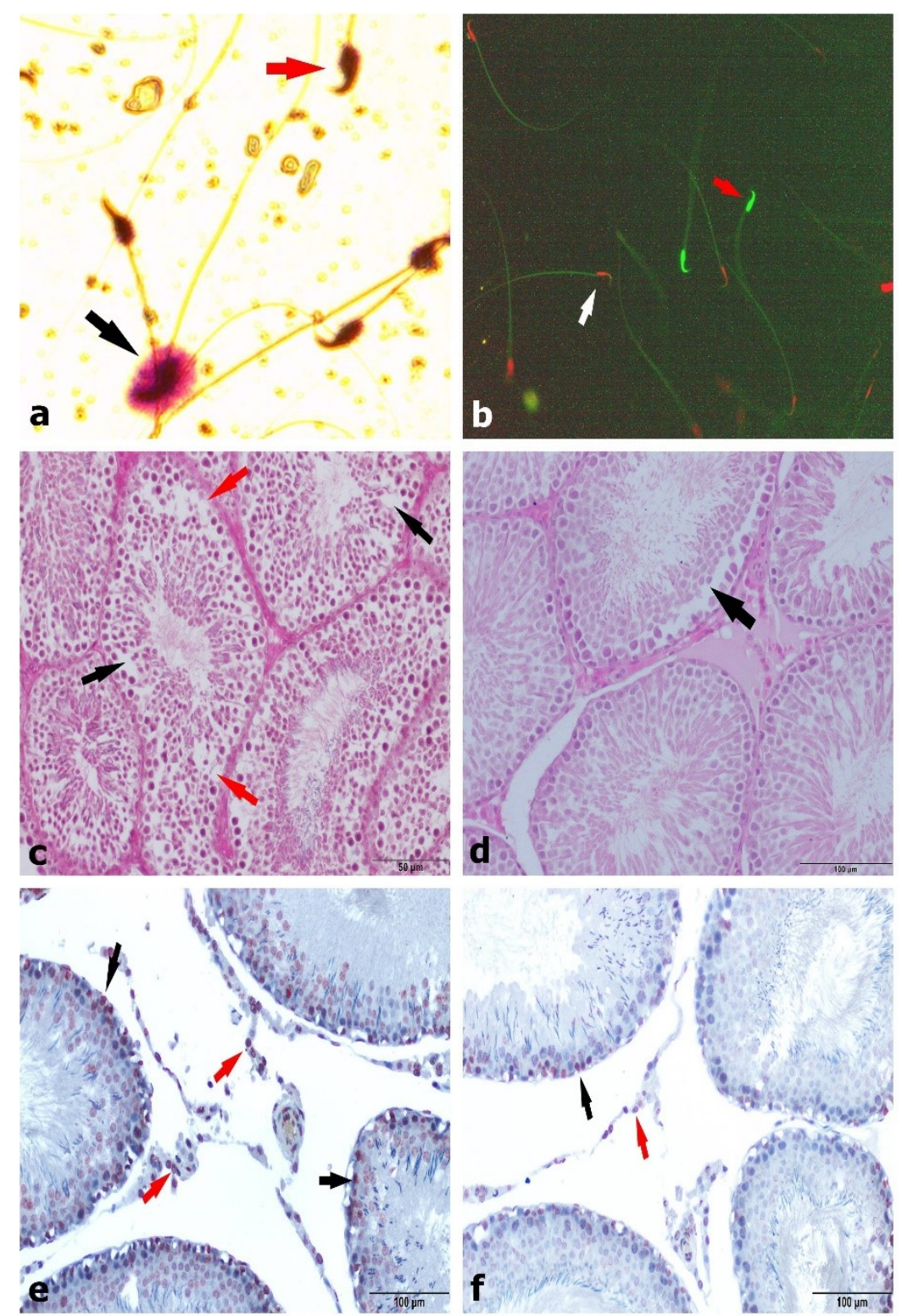

Fig. 1 (a) Sperm cells with DNA fragmentation seen with the halo structure surrounding the head (black arrow). Sperm cells with no DNA fragmentation seen without the halo structure surrounding the head (red arrow); (b) Fluorescent staining of rat spermatozoa with SYBR/PI method (green-fluoresced denote live spermatozoa with intact membranes (red arrow), red-fluoresced indicate dead spermatozoa (white arrow) 200×; (c) RAI group: severe germinal cell loss (red arrow) and detachment of seminiferous tubules (black arrow), H\&E, 400×; (d) RAI + amifostine group: mild detachment in seminiferous tubules (black arrow), H\&E, 400×; (e) RAI group: TUNEL positive intensive apoptotic Leydig cells (red arrow), TUNEL positive apoptotic germ cells (black arrow), 400×; (f) RAI + amifostine group: TUNEL positive a few apoptotic cells in Leydig (red arrow) and germ cells (black arrow), 400× 
The comparison of the control group with group RAI and group RAI + amifostine regarding the testosterone levels showed that there was no significant difference between the groups $(\mathrm{P}<0.05)$. However, the comparison of group RAI with the control group and group RAI + amifostine revealed an increase in FSH level in group RAI, and this increase following RAI therapy was found to be statistically significant $(\mathrm{P}<0.001)$. Furthermore, the serum FSH level of group RAI + amifostine was found to be higher than that of the control group.

The examination of haematoxylin-eosin-stained slides of each group demonstrated that in control group, the testicular tissue had a normal structure characterised by the presence of cross-sections of seminiferous tubules, leydig cells, and the tubule basal membrane. In comparison to the control group, in group RAI, the testicular tissue displayed both degeneration and disorganisation of the seminiferous epithelium, and loss, detachment and vacuolation of the germinal cells (Table 2, Fig. 1c). Damage of the seminiferous tubules of the testes was the greatest in the group that received RAI alone, and the comparison of this group with group RAI + amifostine revealed that the lesions were significantly less severe $(\mathrm{P}<0.001)$ in the group RAI + amifostine than in group Rai (Fig. 1d).

The TUNEL assay, used to detect apoptotic cells, revealed the presence of a high number of apoptotic germ cells in group RAI, and this increased apoptotic cell index significantly differed from the indices of the control group and group RAI + amifostine (Fig. 1e) $(\mathrm{P}<0.001)$. The comparison of both groups showed that the apoptotic cell index decreased in group RAI + amifostine, and this difference was statistically significant (Table 2, Fig. 1f). In all three groups, apoptotic cells were scarce in the interstitial area.

\section{Discussion}

In the present study, the histopathological alterations occurring in the testicular tissue after RAI therapy and the protective effect of amifostine against radiation-induced damage were demonstrated. Radiationinduced damage is most common in tissues characterised by a high rate of cell renewal. The adverse effects of RAI on the gonads seem to be more severe in young men than in women, most probably due to the high sensitivity of spermatogonia to irradiation. Given that the germinal epithelium and in particular, spermatogonia in the testes are highly sensitive to irradiation (13), there is concern that radiation absorbed by the testes following the administration of high doses of radioiodine could cause azoospermia and permanent infertility (15). It has been reported that in men, depending on the level of exposure, RAI may lead to permanent testicular damage and reduced sperm concentration $(2,6)$. In the present study, RAI therapy decreased sperm motility and viability, but no decrease was detected in sperm concentration and TMI. In agreement with the results of the present study, in research conducted by Pacini et al. (20) and Wichers et al. (29), radioactive iodine administration was reported to reduce sperm motility. However, information available on alterations observed in sperm concentration is contradictory. While Handelsman et al. (12) reported that the administration of a single high dose of RAI led to azoospermia, Clyde et al. (5) observed decreased sperm motility associated with oligospermia only in two out of three young men. These researchers indicated that in the third patient, despite reduced motility of spermatozoa, the concentration of sperm was within the normal limits. During the spermatogenesis process, which refers to the formation of sperm from spermatogonia, any damage to the spermatogonia results in the prevention of the formation of new sperm, and eventually in infertility. In rats, this period takes approximately 35 days (4). Therefore, the alteration caused by RAI therapy in sperm quality may be related to the duration of this therapy. Furthermore, the alterations observed in sperm quality may have arisen from several factors, including, among others, administration of RAI, dose absorbed by the testes, and the use of radioprotective agents with or without RAI. In the present study, to minimise normal tissue toxicity, RAI therapy was combined with the administration of the radioprotective agent, amifostine, which led to an increase in sperm motility and viability. The protective effect of amifostine occurs probably through a mechanism that eases the capture of WR-1065 in normal tissues and provides better $\mathrm{pH}$ conditions for alkaline phosphatase activity, which reduces amifostine (WR-2721) to its active metabolite (WR-1065) (7).

Reports on the impact of RAI therapy on endocrine functions are conflicting. The testes appear to have two functionally independent compartments, namely, the Leydig cells, responsive to luteinising hormone (LH), and the seminiferous tubules, responsive to FSH. An increased FSH level points out to a failure of the germinal epithelium and to a significant impairment of spermatogenesis (10). In the present study, similarly to previous reports $(12,20)$, in the group that received RAI, histological examination demonstrated germinal cell loss, detachment of germinal cells from each other, their vacuolation, and degenerative changes of the seminiferous epithelium associated with increased serum FSH levels. Serum FSH level was considered as a more sensitive marker of germinal cell failure than sperm count. Furthermore, sperm quality was shown to be adversely affected. The increase that occurs in plasma FSH levels following the severe damage of seminiferous tubules has been attributed to the absence of a negative feedback from the germinal epithelium. Sperm production in males is maintained by FSH production in the pituitary gland, which is regulated through a negative feedback mechanism in which inhibin, produced by the seminiferous tubules, takes part. Nonetheless, no statistically significant difference was detected between the groups for the serum testosterone levels of the rats. While Hyer et al. (14) and Pacini et al. (20) reported 
testosterone levels within the normal range; Wang et al. (28) detected decreased testosterone levels. Androgen production is maintained by the pituitary production of $\mathrm{LH}$, which is also regulated by a negative feedback mechanism based on the production of testosterone in testicular Leydig cells. In the testes, Leydig cells are more resistant to radiation (up to $24 \mathrm{~Gy}$ ) than germ cells, most likely due to their slow rate of turnover. It was reported that, when human testes are radiated, the germinal epithelium is temporarily damaged and Leydig cell function remains intact (25). Consistent with the high tolerance of Leydig cells to radiation injury, Sklar (26) reported that two men who received more than 4,000 cGy to the testes in late adolescence still maintained normal testosterone levels as adults. Our data are in agreement with data reported in previous studies (14, 20, 26), as only germ cell degeneration was observed after RAI therapy, FSH levels remained high, and testosterone levels may have remained stable due to the Leydig cells not being affected. Another possible explanation is that, since the adrenal gland can also secrete a certain amount of testosterone, it perhaps compensates the loss due to RAI (18). Damage to the wall of the seminiferous tubules was most severe in the group that received RAI, and the comparison of group RAI and group RAI + amifostine showed that a decrease in the damage observed in the latter was statistically significant. The reduced damage to the seminiferous tubules in group RAI + amifostine was accompanied by decreased FSH levels, and unaltered testosterone levels could be attributed to the Leydig cells not being affected by RAI therapy. Furthermore, the occurrence of tissue damage and cell death has been attributed to the inadequate scavenging of free radicals. In fact, there is a protective mechanism to prevent tissue damage caused by free radicals generated during cellular metabolic processes. One of the essential biochemical functions of amifostine is to show an antioxidant effect. Amifostine, which is currently the only agent available for clinical use, is known as a selective cytoprotective agent of normal tissues against the toxicity of chemotherapy and radiotherapy, and acts as a scavenger of free radicals and conjugate of electrophilic substances. WR-2721, a prodrug, which is dephosphorylated by alkaline phosphatase, can activate free thiol metabolites in tissues. The selective protection of non-malignant tissues is believed to be due to the higher alkaline phosphatase activity in normal tissues, different mechanisms of amifostine uptake, and different membrane-bound alkaline phosphatase concentrations (7). In the present study, it was considered that amifostine might have enabled protection by showing an antioxidant effect. On the other hand, although altered measurements of testicular volume and weight may indicate injury of the gonads, our data suggest that germ cell loss is not necessarily associated with the reduction of TMI parameters. Franca and Russell (9) have mentioned that when a massive germ cell loss occurs, it is followed by a sharp decline in testicular morphometric parameters. However, alterations of TMI were not observed in RAI and RAI + amifostine-treated rats in this study. Although germ cell loss was detected, the weight of the testes remained unaltered, which was attributed to lymphatic and/or interstitial oedema that counterbalanced germ cell death and testis weight (27).

As radiation is known to cause alterations in cell DNA, it can be assumed that radiation emitted by RAI may affect the DNA of spermatozoa (17). EsquerréLamare et al. (6) detected a transient increase in sperm DNA fragmentation 3.25 months after the administration of a single dose of $150 \mathrm{mCi}$ of radioiodine. Bujan et al. (1) determined that sperm DNA fragmentation reached its highest level within six months after chemotherapy and radiotherapy in men with thyroid cancer. Amifostine shows a protective effect by scavenging free radicals, protecting DNA, and accelerating DNA repair. In the present study, the comparison of group RAI with group RAI + amifostine for the sperm DNA fragmentation index, showed that the decrease observed in the latter was statistically significant. It is considered that amifostine might have shown its radioprotective effect by scavenging the free radicals generated as a result of radiotherapy and by repairing the free radical-induced damage to DNA by donating hydrogen. The tissue protection provided by amifostine against radiotherapyinduced DNA damage is attributed to amifostine being converted into WR-1065 and other thiol metabolites. WR1065 not only acts as a reactive oxygen species scavenger; it also stabilises intact DNA inside the normal cell nucleus by inhibiting DNA intercalation and breakage caused by antineoplastic drugs, and improves the self-repair ability of DNA (7). While the phosphorus in the structure of amifostine maintains the inactive form of this compound, the sulphur it contains gives amifostine a radical scavenging activity. To our knowledge, there is no previous study on the protective effect of the combined use of RAI therapy and amifostine on sperm DNA. On the other hand, it has been determined that when used as a radioprotector, amifostine is highly effective in protecting sperm DNA.

Reports indicate that radiation causes apoptosis as a result of its direct effect on DNA. While spontaneous apoptosis is a physiological process that occurs during the development of germ cells and enables the elimination of damaged germ cells, it can also be induced by several external factors including ionising radiation, chemotherapy, and hormonal manipulations (8). Recent research suggests that radioiodine induction causes germ cell apoptosis. In the present study, many apoptotic cells were observed among the germ cells of the seminiferous tubules in group RAI, and when compared to the control group, this increase in the number of apoptotic cells was found to be statistically significant $(\mathrm{P}<0.001)$. In group RAI, very few apoptotic cells were present in the interstitial area. When compared to group RAI, a decrease in the number of apoptotic cells in group RAI + amifostine was observed, and a statistically significant difference was detected between these two groups for the number of apoptotic cells $(\mathrm{P}<0.001)$. Yet it has been reported that amifostine 
shows a protective effect against radiation-induced apoptosis in testicular germ cells in rats, while some other previous research has shown that amifostine has no anti-apoptotic effect (3).

In conclusion, the present study showed that RAI administration was toxic for the testicular tissue and induced apoptosis, which damaged its histological structure. Furthermore, it was demonstrated that administration of amifostine prior to RAI therapy enabled the functional and histopathological protection of the testes and also exerted a protective effect on sperm parameters.

Conflict of Interests Statement: The authors declare that there is no conflict of interests regarding the publication of this article.

Financial Disclosure Statement: This study was funded by authors. The resources (materials, reagents) were financed from the authors' own means.

Animal Rights Statement: Approval for the study was granted by the Local Animal Ethics Committee and all procedures were performed in accordance with the National Guidelines for the Use and Care of Laboratory Animals.

Acknowledgements: The authors are thankful to Sukru Gurler and Mushap Kuru for the help with statistical analysis of the study.

\section{References}

1. Bujan L., Walschaerts M., Moinard N., Hennebicq S., Saias J., Brugnon F., Auger J., Berthaut I., Szerman E., Daudin M., Rives N.: Impact of chemotherapy and radiotherapy for testicular germ cell tumors on spermatogenesis and sperm DNA: a multicenter prospective study from the CECOS network. Fertil Steril 2013, doi:10.1016/j.fertnstert.2013.05.018.

2. Ceccarelli C., Battisti P., Gasperi M., Fantuzzi E., Pacini F., Gualdrini G., Pierantoni M.C., Luciani A., Djokich D., Pinchera A.: Radiation dose to the testes after 131I therapy for ablation of post surgical thyroid remnants in patients with differentiated thyroid cancer. J Nucl Med 1999, 40, 1716-1721.

3. Celik K.O., Aras A., Tugan D., Hekimgil M., Yalman D., Esassolak M., Haydaroglu A.: The relationship between radiationinduced apoptosis in rat germ cells and amifostine. T Klin J Med Sci 2004, 24, 142-146.

4. Clouthier D.E., Averbock M.R., Maika S.D., Hammer R.E., Brinster R.L.: Rat spermatogenesis in mouse testis. Nature 1996, doi:10.1038/381418a0.

5. Clyde H.R., Walsh P.C., English R.W.: Elevated plasma testosterone and gonadotropin levels in infertile males with hyperthyroidism. Fertil Steril 1976, 27, 662-666.

6. Esquerré-Lamare C., Isus F., Moinard N., Bujan L.: Sperm DNA fragmentation after radioiodine treatment for differentiated thyroid cancer. Basic Clin Androl 2015, doi: 10.1186/s12610015-0024-1.

7. Etebari M., Jafarian-Dehkordi A., Lame V.: Evaluation of protective effect of amifostine on dacarbazine induced genotoxicity. Res Pharm Sci 2005, 10, 68-74.

8. Evan G., Littlewood T.: A matter of life and cell death. Science 1998, 281, 1317-1321.

9. Franca L.R., Russel L.D.: The testis of domestic animals. In: Male reproduction: a multidisciplinary overview, edited by F. MartinezGarcia, J. Regadera, Madrid, 1998, pp. 198-219.
10. Gudeloglu A., Parekattil S.J.: Update in the evaluation of the azoospermic male. Clinics (Sao Paulo) 2013, 68, 27-34.

11. Sen C.C., Yumusak N., Faundez R., Temamogullari., Taskin A.: Evaluation of intra-testicular injections of calcium chloride and 4-vinylcyclohexene 1,2 monoepoxide for chemical sterilization in guinea pigs. Pol J Vet Sci 2017, doi:10.1515/pjvs-2017-0030.

12. Howell S.J., Shalet S.M.: Spermatogenesis after cancer treatment: damage and recovery. J Natl Cancer Inst Monogr 2005, doi:10.1093/jncimonographs/lgi003.

13. Hyer S., Vini L., O'Connell M., Pratt B., Harmer C.: Testicular dose and fertility in men following I(131) therapy for thyroid cancer. Clin Endocrinol (Oxf) 2002, 56, 755-758.

14. Krassas G.E.: The male and female reproductive system in thyrotoxicosis. In: the thyroid: A fundamental and clinical text, edited by S.C. Werner, S.H. Ingbar, L.E. Braverman, R.D. Utiger, Philadelphia, 2005, pp. 621-628.

15. Kuker R., Sztejnberg M., Gulec S.: I-124 imaging and dosimetry. Mol Imaging Radionucl Ther 2017, doi:10.4274/2017.26.suppl.07.

16. Lassmann M., Hanscheid H., Gassen D., Biko J., Meineke V., Reiners C., Scherthan H.: In vivo formation of gamma-H2AX and 53BP1 DNA repair foci in blood cells after radioiodine therapy of differentiated thyroid cancer. J Nucl Med 2010, doi:10.2967/jnumed.109.071357.

17. Luo D.Y., Yang G., Liu J.J., Yang Y.R, Dong Q.: Effects of varicocele on testosterone, apoptosis and expression of StAR mRNA in rat Leydig cells. Asian J Androl 2011, doi:10.1038/aja.2010.111

18. Ozturk M.I, Koca K., Keles M.O., Yilmaz S., Karaman M.I. Increased sperm DNA damage in experimental rat varicocele model and the beneficial effect of varicocelectomy. Int J Fertil Steril 2012, 6, 95-100.

19. Pacini F, Gasperi M, Fugazzola L., Ceccarelli C., Lippi F., Centoni R., Martino E., Pinchera A.: Testicular function in patients with differentiated thyroid carcinoma treated with radioiodine. J Nucl Med 1994, 35, 1418-1422.

20. Robbins R.J., Schlumberger M.J.: The evolving role of (131)I for the treatment of differentiated thyroid carcinoma. J Nucl Med 2005, 46, 28-37.

21. Sahintürk V., Güclü C., Baycu C.: Protective effects of vitamin E on ethane dimethane sulfonate-induced testicular toxicity in rats. Asian J Androl 2007, doi:10.1111/j.1745-7262.2007.00229.x.

22. Sakhaee E., Abshenas J., Kheirandish R., Azari O., Mirzabeigi F., Mostafavi A.: Adverse effects of Zataria multiflora boiss on epididymal sperm quality, and testicular tissue following experimentally induced copper poisoning in mice. Basic Res J Med Clin Sci 2013, 2, 27-31.

23. Si W., Benson J.D., Men H., Critser J.K.: Osmotic tolerance limits and effects of cryoprotectants on the motility, plasma membrane integrity and acrosomal integrity of rat sperm. Cryobiology 2006, doi: 10.1016/j.cryobiol.2006.09.001.

24. Simon B., Lee S.J., Partridge A.H., Runowicz C.D: Preserving fertility after cancer. CA Cancer J Clin 2005, 55, 211-228.

25. Sklar C.: Reproductive physiology and treatment-related loss of sex hormone production. Med Pediatr Oncol 1999, 33, 2-8.

26. Vendramini V., Sasso-Cerri E., Miraglia S.M.: Amifostine reduces the seminiferous epithelium damage in doxorubicintreated prepubertal rats without improving the fertility status Reprod Biol Endocrinol 2010, doi: 10.1186/1477-7827-8-3.

27. Wang S.J., Jin J.H., Xu J.X., Wu Z.F., Lu K.Y., Li C.G., Lei Z.L., Li S.J: Radioiodine-131 therapy improves sex hormones and sexual function in male patients with Graves' disease. Zhonghua Nan Ke Xue 2012, 18, 542-544.

28. Wichers M., Benz E., Palmeto H., Biersack H.J., Grunwald F., Klingmuller D.: Testicular function after radioiodine therapy for thyroid carcinoma. Eur J Nucl Med 2000, 27, 503-507.

29. Xu G., Zhang W., Bertram P., Zheng XF., McLeod H.: Pharmacogenomic profiling of the PI3K/PTEN-AKT- mTOR pathway in common human tumors. Int J Oncol 2004, 24, 893900. 